\title{
Rola satysfakcji z pracy oraz przywiązania do organizacji dla zamiaru jej opuszczenia. Weryfikacja modelu
}

\begin{abstract}
The aim of the study was verified job satisfaction mediating role between organizational commitment and intention to quit the organization. Additionally checked if job satisfaction and organizational commitment mediate between salary satisfaction and intention to quit the organization. Subjects were 484 employees from one IT organization. According to results job satisfaction partially mediated between affective commitment and intention to quit the organization as well as totally mediated between normative commitment and intention to quit. Additionally job satisfaction, affective commitment as well as continuance commitment partially mediated between salary satisfaction and intention to quit the organization.
\end{abstract}

Keywords: job satisfaction, salary satisfaction, organizational commitment, intention to quit the organization

\section{Wstęp}

7 mniejszające się bezrobocie w Polsce, napływ pracowników z Ukrainy, ujemny przyrost naturalny, a co za tym idzie starzenie się społeczeństwa, czy wreszcie pojawienie się na rynku pracy przedstawicieli pokolenia Y to tylko niektóre czynniki wpływające na przystosowanie się przedstawicieli organizacji i pracodawców 
do nowych realiów rynku pracy i zmianę swoich dotychczasowych postaw wobec pracowników. Z nieoficjalnych danych wynika, że obecnie w Polsce pracuje ponad milion Ukraińców, których napływ zmniejsza poziom bezrobocia. Według danych GUS bezrobocie w czwartym kwartale 2016 roku w stosunku do 2015 roku spadło średnio o 1,4\%. W końcu kwietnia 2017 roku wskaźnik osób bezrobotnych wyniósł 7,7\%, natomiast na koniec czerwca 2019 roku 5,3\% i był to najniższy poziom w ciągu ostatnich 29 lat. Biorąc pod uwagę fakt, iż znacząca część osób zarejestrowanych w Urzędach Pracy ze względu na działalność w szarej strefie nie jest faktycznie zainteresowana legalnym zatrudnieniem, to wskaźnik ten z pewnością jest mniejszy, skoro udział szarej strefy w PKB wynosi około $20 \%{ }^{1}$. Instytut Prognoz i Analiz (IAPG) szacuje, że udział szarej strefy w polskiej gospodarce wyniesie w 2019 roku 17,2\%. Dodatkowo pracownicy pokolenia Y, czyli osoby urodzone po 1980 roku, z powodu braku chęci przywiązywania się do organizacji, sceptycyzmu wobec lojalności czy częstych zmian pracy są grupą wymuszającą na pracodawcach i ich przedstawicielach podejmowanie wobec nich zabiegów nastawionych na utrzymanie w dotychczasowym miejscu pracy².

W przedstawionym kontekście działania przedstawicieli jednostek organizacyjnych zajmujących się zarządzaniem zasobami ludzkimi koncentrują się na wzroście motywacji pracowników do pozostawania w aktualnym miejscu pracy jako kluczowego celu strategii personalnej. Utrzymanie pracownika jest korzystne dla organizacji ze względu na potencjalne trudności z obsadzeniem wakatu, niską efektywność w czasie okresu wdrożenia jego następcy, znajomość realiów firmy, jej wartości, kultury organizacyjnej, kontaktów z kontrahentami, relacje z innymi pracownikami itp. Poza dbaniem o ogólną satysfakcję z pracy również obecna na rynku pracy presja płacowa mobilizuje pracodawców i ich przedstawicieli do takiego kształtowania systemów wynagrodzeń, aby pracownik był zadowolony z wynagrodzenia, a dzięki temu pozostał jak najdłużej w organizacji. Również inne działania ze strony pracodawców wdrażane przez pracowników zajmujących się zarządzaniem zasobami ludzkimi, takie jak badanie doświadczeń pracowników (employee experience), ich satysfakcji z pracy, poszukiwanie nowych benefitów czy zaangażowanie w inicjatywy odnoszące się do społecznej odpowiedzialności biznesu mają na celu przekonanie osób zatrudnionych, że organizacja dba o ich dobrostan, a w związku z tym warto się do niej przywiązać i pozostać w niej jak najdłużej.

Celem niniejszego artykuł jest weryfikacja oddziaływania satysfakcji z pracy, zadowolenia z wynagrodzenia oraz trzech przejawów przywiązania organizacyjnego na zamiar opuszczenia organizacji. W ramach stworzonego modelu badawczego

${ }^{1}$ J. Fundowicz, K. Łapiński, M. Peterlik, B. Wyżnikiewicz, Szara strefa w polskiej gospodarce w 2016 roku, Instytut Badań Nad Gospodarką Rynkową, Warszawa 2016.

2 S. Stachowska, Oczekiwania przedstawicieli pokolenia $Y$ wobec pracy i pracodawcy, „Zarządzanie Zasobami Ludzkimi” 2012, nr 2(85), ss. 33-56. 
sprawdzano również, czy poszczególne wymiary przywiązania organizacyjnego są bezpośrednio związane z zamiarem opuszczenia organizacji, czy być może w tej relacji pośredniczy satysfakcja z pracy, co oznaczałoby, że im wyższy poziom przywiązania organizacyjnego prezentują pracownicy, tym większa jest ich satysfakcja z pracy, dzięki czemu nie mają motywacji do jej opuszczenia.

\section{Satysfakcja z pracy i przywiązanie do organizacji a zamiar jej opuszczenia}

Według najbardziej ugruntowanej w literaturze przedmiotu koncepcji przywiązania do organizacji obejmuje ono trzy wymiary: emocjonalny, kontynuacyjny oraz normatywny ${ }^{3}$.

Przywiązanie emocjonalne do organizacji można scharakteryzować jako posiadanie silnej więzi z organizacją, której przejawem jest identyfikacja z jej wartościami, zaangażowanie w realizację wyznaczonych celów biznesowych, poczucie dumy i satysfakcji wynikającej z pracy, jak również troszczenie się o jej wizerunek ${ }^{4}$.

Przywiązanie normatywne do organizacji prezentują pracownicy, którzy traktują dalszy pobyt w organizacji jako powinność względem niej, uważając, że są jej coś winni. Powinność ta współgra z przeświadczeniem o postawie zgodnej z celami organizacji, a jej źródłem jest wiara, iż jest to właściwe i moralnie uzasadnione ${ }^{5}$. Wydaje się, że przyczyny takiej postawy tkwią w wyuczonych w procesie socjalizacji przekonaniach o potrzebie bycia lojalnym i oddanym, które ulegają generalizacji, wpływając na decyzję o dalszym pozostawaniu w organizacji. Niedochowanie wierności tym wartościom może się wiązać z dyskomfortem, poczuciem winy i niezadowolenia z własnej postawy, wzmacniając tym samym prawdopodobieństwo pozostania wiernym i lojalnym wobec jednej organizacji.

Przywiązanie kontynuacyjne charakteryzuje osoby, które rozważają dalszy pobyt w organizacji w kategoriach ewentualnych zysków i strat ${ }^{6}$. Mają one obawę przed tym, że nie znajdą lepszej pracy, dającej więcej korzyści, a ewentualna zmiana będzie się wiązała ze zbyt dużymi kosztami. Ich postawa charakteryzuje się wyrachowaniem i koncentracją na własnych interesach. Ta forma przywiązania

${ }^{3}$ N.J. Allen, J.P. Meyer, The measurement and antecedents of affective, continuance, and normative commitment to the organization, „Journal of Occupational Psychology” 1990, nr 63, ss. $1-18$.

${ }^{4}$ N.J. Allen, J.P. Meyer, Affective, continuance, and normative commitment to the organization: An examination of construct validity, „Journal of Vocational Behavior” 1996, nr 3(49), ss. $252-276$

5 J.P. Meyer, D.J. Stanley, L. Herscovitch, L. Topolnytsky, Affective, continuance, and normative commitment to the organization: A meta-analysis of antecedents, correlates, and consequences, „Journal of Vocational Behavior” 2002, nr 61, 20-52.

${ }^{6}$ R.M. Kanter, Commitment and Community, Harvard University Press, Cambridge 1976. 
jest wynikiem wpływu na pracownika czynników zewnętrznych, takich jak wynagradzanie, sytuacja na rynku pracy czy prestiż stanowiska, a nie oddziaływaniem czynników natury wewnętrznej.

Autorzy koncepcji przywiązania do organizacji podkreślają, że przywiązanie normatywne, emocjonalne czy kontynuacyjne to nie odmienne typy przywiązania do organizacji, tylko jego wymiary, które mogą ze sobą współwystępować w różnym nasileniu ${ }^{7}$. Oznacza to, że pracownik może nie mieć motywacji do zmiany pracy, zarówno ze względu na istnienie u niego równocześnie, ale w różnym stopniu przywiązania emocjonalnego, kontynuacyjnego i normatywnego. Pracownik deklarujący w największym stopniu przywiązanie kontynuacyjne pozostaje zatem w organizacji z powodu utraty korzyści związanych z brakiem zmiany pracy oraz kosztów kojarzonych z odejściem, co nie oznacza, że nie chce zmienić pracy również ze względu na przywiązanie normatywne, czyli z poczucia bycia lojalnym wobec organizacji i poczucia obowiązku wobec niej, jak również z powodu przywiązania emocjonalnego, czyli silnej emocjonalnej więzi z organizacją i identyfikowania się z jej celami. Każdy z przejawów przywiązania organizacyjnego dostarcza pracownikowi odmiennych powodów do pozostania w organizacji. Osoby przejawiające wysoki poziom przywiązania emocjonalnego kontynuują pracę w organizacji, ponieważ tego „chcą”. Pracownicy o wysokim nasileniu przywiązania kontynuacyjnego pozostają w organizacji, ponieważ „muszą”. Osoby charakteryzujące się wysokim poziomem przywiązania normatywnego pracują nadal w organizacji, gdyż mają przekonanie o tym, że „powinni”8.

Zadowolenie z pracy jest definiowane jako postawa wobec pracy, która obejmuje dwa aspekty - emocjonalny, czyli uczucia względem pracy, oraz poznawczy, który dotyczy oceny pracy ${ }^{9}$. Aspekt poznawczy zadowolenia z pracy jest nazywany satysfakcją z pracy, a aspekt emocjonalny określany jest albo jako ocena emocjonalna pracy, albo samopoczucie, albo jako nastrój w miejscu pracy ${ }^{10}$. Satysfakcja z pracy może dotyczyć sądów i ocen, zarówno wobec pracy jako całości, jak i jej części, takich jak wynagrodzenie, awans czy rozwój zawodowy ${ }^{11}$. Oba ujęcia zadowolenia z pracy mają swoje źródła w koncepcjach szczęścia. Ocena satysfakcji z pracy ma swoje korzenie w eudajmonistycznej koncepcji szczęścia, natomiast afektywne wskaźniki oceny pracy odwołują się do założeń hedonistycznej teorii

${ }^{7}$ N.J.Allen, J.P. Meyer, A three-component conceptualization of organizational commitment, „Human Resource Management Review” 1991, nr 1(1), ss. 61-89.

${ }^{8}$ N.J. Allen, J.P. Meyer, The measurement and antecedents..., ss. 1-18.

${ }^{9}$ D.W. Organ, J.P. Near, Cognitive vs. affect measures of job satisfaction, „International Journal of Psychology" 1985, nr 20, ss. 241-254.

${ }^{10}$ A. Zalewska, Reactivity and Job Satisfaction at a New Workplace, „Polish Psychological Bulletin” 2001, nr 3(32), ss. 167-174.

${ }^{11}$ E.A. Locke, The nature and causes of job satisfaction, w: Handbook of industrial and organizational psychology, red. M.D. Dunnette, Rand McNally, Chicago 1976, ss. 1297-1349. 
szczęścia ${ }^{12}$. Ma ona swoje podstawy w filozofii greckiego myśliciela Arystypa z Cyreny, który uważał, że głównym celem życia jest doświadczanie maksymalnej ilości przyjemności w danym momencie stanowiącej o szczęściu, do którego powinno się dążyć poprzez intensyfikację emocji o charakterze pozytywnym i unikanie emocji o charakterze negatywnym. Eudajmonistyczna koncepcja szczęścia odwołuje się do filozofii Arystotelesa, zgodnie z którą człowiek powinien żyć w zgodzie z wewnętrznym duchem „dajmonem” stanowiącym wszystkie jego potencjalności. Ich aktualizacja prowadzi do najwyższego spełnienia w życiu oraz osiągnięcia samoaktualizacji zwanej eudajmonią ${ }^{13}$. W przedstawionym kontekście atrybutami zadowolonego pracownika powinna być z jednej strony praca zgodna z posiadanymi predyspozycjami i potencjałem, stanowiąca o satysfakcji z pracy, a z drugiej praca pełna przyjemności i pozytywnych emocji, a wolna od przykrości i negatywnych stanów emocjonalnych. Satysfakcja z pracy ma subiektywny charakter i jest zdeterminowana indywidualną percepcją danego pracownika. Ocena satysfakcji z pracy jest więc uwikłana w jego „wewnętrzny świat”, który stanowią jego własne pragnienia, potrzeby czy wartości, ale również możliwość wykonywania pracy zgodnej z posiadanymi umiejętnościami i predyspozycjami. W przypadku przywiązania emocjonalnego wartością wpływającą na ocenę satysfakcji z pracy może być przynależność, w odniesieniu do przywiązania normatywnego lojalność i oddanie, natomiast w przypadku przywiązania kontynuacyjnego wyrachowanie i własny interes. Wyniki badań potwierdzają pozytywne związki pomiędzy wymiarami przywiązania organizacyjnego a satysfakcją z pracy ${ }^{14}$.

Satysfakcja z pracy oraz przywiązanie organizacyjne są kluczowymi czynnikami w zamiarze odejścia z organizacji ${ }^{15}$.

W zdecydowanej większości badań dotyczących zamiaru odejścia z organizacji ich autorzy stosują globalne wskaźniki satysfakcji z pracy oraz tylko jeden z przejawów przywiązania organizacyjnego w postaci przywiązania emocjonalnego. Rzadziej są wykorzystywane bardziej szczegółowe wskaźniki satysfakcji z pracy

${ }_{12}$ M. Wnuk, Hedonizm, eudajmonizm oraz przepływ/zaangażowanie jako trzy nurty badań nad szczęściem, „Hygeia Public Health” 2013, nr 3(48), ss. 285-288.

13 Ibidem.

${ }^{14}$ T. Guimaraes, M. Igbaria, Antecedents and consequences of job satisfaction among information center employees, „Journal of Management Information Systems” 1993, nr 4(9), ss. 145-174; D.E. Trimble, Organizational commitment, job satisfaction, and turnover intention of missionaries, „Journal of Psychology and Theology” 2006, nr 4(34), ss. 349-360; L. Lum, J. Kervin, K. Clark, F. Reid, W. Sirola, Explaining nursing turnover intent: job satisfaction, pay satisfaction, or organizational commitment?, „Journal of Organizational Behavior” 1998 nr 3(19), ss. 305-320.

${ }^{15}$ C.M. Riordan, R.W. Griffeth, The opportunity for friendship in the workplace: An underexplored construct, „Journal of Business and Psychology” 1995, nr 10, ss. 141-154; W. van Breukelen, R. van der Vlist, H. Steensma, Voluntary employee turnover: combining variables for the traditional turnover literature with the theory of planned behavior, „Journal of Organizational Behavior” 2004, nr 25, ss. 893-914. 
odzwierciedlające zadowolenie z jej poszczególnych aspektów, takich jak wynagrodzenie, awans, współpracownicy oraz inne wymiary przywiązania organizacyjnego, takie jak przywiązanie normatywne i kontynuacyjne ${ }^{16}$.

Wyniki zdecydowanej większości badań wskazują na to, że satysfakcja z pracy jest silniejszym predyktorem chęci odejścia z organizacji niż przywiązanie do organizacji.

Wśród pracowników fizycznych z Hiszpanii zatrudnionych w firmie produkującej autobusy oraz dostarczającej wodę satysfakcja z pracy była silniejszym predyktorem chęci zmiany pracy niż przywiązanie emocjonalne ${ }^{17}$. Również dla pracowników hoteli tureckich z Ankary, zarówno satysfakcja z pracy, jak i przywiązanie emocjonalne były zmiennymi negatywnie związanymi z zamiarem odejścia z pracy. Analogiczne rezultaty otrzymano w badaniach Christine M. Riordan i Rodger W. Griffeth ${ }^{18}$ oraz Doreen Tan i Syed Akhtar ${ }^{19}$, gdzie poza przywiązaniem emocjonalnym zastosowano również wskaźniki pozostałych wymiarów przywiązania do organizacji.

Ożywiona dyskusja toczy się wokół tego, czy satysfakcja z pracy poprzez przywiązanie do organizacji częściowo wpływa na zamiar jej opuszczenia, czy może jest odwrotnie, czyli satysfakcja z pracy jest częściowym mediatorem w relacji między przywiązaniem organizacyjnym a chęcią opuszczenia organizacji.

W pierwszym przypadku oznacza to, że satysfakcja z pracy pracownika oddziałuje pozytywnie na jego przywiązanie do organizacji, które z kolei sprzyja pozostaniu w aktualnym miejscu pracy. Zgodnie z przeciwstawnym ujęciem to przywiązanie pracownika do organizacji kształtuje pozytywnie satysfakcję z pracy, sprzyjając pośrednio brakowi motywacji do jej opuszczenia.

Oba zastosowane ujęcia znajdują odzwierciedlenie w dotychczasowych wynikach badań, choć większość z nich potwierdza, że satysfakcja z pracy pełni rolę częściowego mediatora pomiędzy przywiązaniem pracownika do organizacji a zamiarem jej opuszczenia, czyli, że przywiązanie do organizacji oddziałuje na zamiar opuszczenia organizacji zarówno bezpośrednio, jak i pośrednio poprzez satysfakcję z pracy.

Analiza wyników badań dokonana na 178 grupach badanych ze 155 badań dowiodła, że zarówno przywiązanie emocjonalne, jak również satysfakcja z pracy są odrębnymi predyktorami zamiaru odejścia z organizacji. Oznacza to, że model całkowitej mediacji, niezależnie od tego, czy zmienną pośredniczącą jest satys-

${ }^{16}$ R.P Tett., J.P. Meyer, Job satisfaction, organizational commitment, turnover intention, and turnover: Path analyses based on meta-analytic findings, „Personnel Psychology” 1993, nr 46, ss. 259-293.

${ }^{17}$ C. Anton, The impact of role stress on workers' behaviour through job satisfaction and organizational commitment, „International Journal of Psychology” 2009, nr 3(44), ss. 187-194.

${ }^{18}$ C.M. Riordan, R.W. Griffeth, The opportunity for friendship in the workplace...

19 D. Tan, S. Akhtar, Comparison of job-facet satisfaction and commitment, determinants of turnover intention, „, The International Journal of Employment Studies” 1995 3(1), ss. 35-51. 
fakcja z pracy, czy przywiązanie emocjonalne, nie jest modelem właściwym ${ }^{20}$. Okazało się, że przywiązanie emocjonalne nie wyjaśnia większej części wariancji zamiaru odejścia z pracy niż satysfakcja z pracy i jest tylko umiarkowanie związane z zamiarem opuszczenia organizacji, co sugeruje, że to raczej satysfakcja z pracy częściowo pośredniczy między przywiązaniem emocjonalnym pracownika do organizacji a zamiarem jej opuszczenia niż odwrotnie ${ }^{21}$.

Hip o te za 1. Prawdopodobnie satysfakcja z pracy jest częściowym mediatorem między trzema przejawami przywiązania do organizacji w postaci przywiązania emocjonalnego, kontynuacyjnego oraz normatywnego a chęcią jej opuszczenia.

Jednym z aspektów satysfakcji z pracy, który może oddziaływać na zamiar pozostania $\mathrm{w}$ organizacji, jest zadowolenie $\mathrm{z}$ otrzymywanego wynagrodzenia. W badaniach przeprowadzonych na reprezentantach handlowych belgijskiego koncernu farmaceutycznego oraz obywatelach Belgii z różnych organizacji przywiązanie emocjonalne do organizacji oraz spostrzegane poświęcenie wobec organizacji pośredniczyły całkowicie w relacji pomiędzy zadowoleniem z wynagrodzenia a zamiarem odejścia z organizacji ${ }^{22}$. Również w badaniach Lillie Lum i współpracowników ${ }^{23}$ zadowolenie z wynagrodzenia było zarówno bezpośrednio, jak i pośrednio związane z chęcią odejścia z pracy. Efekt bezpośredni był silniejszy niż efekt pośredni, a zmiennymi pośredniczącymi w tym związku była satysfakcja z pracy i przywiązanie emocjonalne do organizacji.

Rizqi Nur'aini A'yuninnisa i Ridwan Saptoto ${ }^{24}$ w swoich badaniach nad pracownikami z branży automotive z Indonezji potwierdzili, że zadowolenie z wynagrodzenia ma zarówno bezpośredni, jak i pośredni wpływ na zamiar zmiany pracy poprzez przywiązanie do organizacji. Wśród pracowników z Hong Kongu zadowolenie $\mathrm{z}$ wynagrodzenia było pośrednio związane z chęcią opuszczenia organizacji, a mediatorem $w$ tej relacji było przywiązanie normatywne ${ }^{25}$.

Na podstawie analizy literatury przedmiotu można stwierdzić, że zadowolenie z wynagrodzenia oddziałuje na zamiar odejścia z organizacji na trzy sposoby. Pierwszy opiera się na bezpośrednim wpływie, dwa kolejne na pośredniczącej roli przywiązania organizacyjnego oraz satysfakcji z pracy. Oznacza to, że im większe zadowolenie ze swojego wynagrodzenia deklaruje pracownik, tym większa jest jego

20 R.P. Tett, J.P. Meyer, Job satisfaction, organizational commitment, turnover intention, and turnover...

21 Ibidem.

${ }^{22} \mathrm{Ch}$. Vandenberghe, M. Tremblay, The role of pay satisfaction and organizational commitment in turnover intentions: A two-sample study, „Journal of Business Psychology” 2008, nr 22, ss. 275-286.

23 L. Lum, J. Kervin, K. Clark, F. Reid, W. Sirola, Explaining nursing turnover intent...

24 R.N. A'yuninnisa, R. Saptoto, The effects of pay satisfaction and affective commitment on turnover intention, „International Journal of Research Studies in Psychology” 2015, nr 2(4), ss. 57-70.

25 D. Tan, S. Akhtar, Comparison of job-facet satisfaction and commitment... 
satysfakcja z pracy oraz przywiązanie do organizacji, co z kolei skutkuje brakiem motywacji do zmiany pracy. Wydaje się, że u podłoża mechanizmu wpływu zadowolenia z wynagrodzenia na zamiar opuszczenia organizacji może leżeć reguła wzajemności ${ }^{26}$. Nakazuje ona pracownikowi odwdzięczenie się za otrzymane dobro, którego dawcą jest organizacja, a jego przedmiotem wynagrodzenie pracownika. W przypadku gdy uznaje on, że wynagrodzenie jest satysfakcjonujące, wyrazem jego wdzięczności może być przywiązanie do organizacji, które skutkuje brakiem chęci jej opuszczenia. Z odwrotną sytuacją mamy do czynienia, jeśli według niego otrzymywane wynagrodzenie nie jest zadawalające, czego konsekwencją jest niechęć wobec przywiązywania się do organizacji i wzrost motywacji do zmiany pracy.

Hip oteza 2. Prawdopodobnie satysfakcja z pracy jest zmienną, która częściowo pośredniczy pomiędzy zadowoleniem z wynagrodzenia a zamiarem opuszczenia organizacji.

Hip oteza 3. Prawdopodobnie emocjonalne, kontynuacyjne i normatywne przywiązanie do organizacji częściowo pośredniczą między zadowoleniem z wynagrodzenia a zamiarem opuszczenia organizacji.

\section{Metody}

\subsection{Opis badanej grupy}

Ankieta miała anonimowy i dobrowolny charakter. Badanie przeprowadzono wśród pracowników jednej dużej organizacji z branży teleinformatycznej. Spośród wszystkich zatrudnionych ankietę wypełniło 484 osób. Ankieta składała się z metryczki stanowiącej pytania o charakterze socjodemograficznym, takie jak wiek, płeć, wykształcenie, oraz pytań z opisanych poniżej narzędzi badawczych będących wskaźnikami satysfakcji z pracy, zadowolenia z wynagrodzenia, przywiązania emocjonalnego, normatywnego oraz kontynuacyjnego do organizacji, jak również zamiaru opuszczenia organizacji. Rozkład zmiennych socjodemograficznych został zaprezentowany w tabeli 1.

\subsection{Narzędzia badawcze}

Zastosowano następujące narzędzia badawcze: Skalę Przywiązania Organizacyjnego w adaptacji Wnuka ${ }^{27}$, pytania z Kwestionariusza Oceny Organizacji Michigan dotyczące satysfakcji z pracy, pytania z Przeglądu Diagnostycznego Pracy Hackman

26 A.W. Gouldner, The norm of reciprocity: A preliminary statement, „American Sociological Review” 1960, nr 2(25), ss. 161-178.

27 M. Wnuk, Właściwości psychometryczne polskiej wersji Skali Przywiqzzania do Organizacji autorstwa Allen i Meyer, „Organizacja i Kierowanie” 2017, nr 3(177), ss. 109-125. 
Tabela 1. Statystyki demograficzne $(N=484)$

\begin{tabular}{|c|c|c|}
\hline Zmienna & Klasyfikacja & Procent lub średnia \\
\hline \multirow{2}{*}{ Płeć } & mężczyźni & $80 \%$ \\
\hline & kobiety & $20 \%$ \\
\hline Wiek & - & 31,5 lat \\
\hline \multirow{3}{*}{ Staż pracy } & krótki (1-12 miesięcy) & $21,7 \%$ \\
\hline & średni (12-48 miesięcy) & $30,6 \%$ \\
\hline & długi (powyżej 48 miesięcy) & $47,7 \%$ \\
\hline \multirow{4}{*}{ Wykształcenie } & podstawowe & $0 \%$ \\
\hline & zawodowe & $3,55 \%$ \\
\hline & średnie & $51,53 \%$ \\
\hline & wyższe & $44,92 \%$ \\
\hline \multirow{2}{*}{$\begin{array}{l}\text { Miejsce w strukturze or- } \\
\text { ganizacyjnej }\end{array}$} & kierownictwo & $19,8 \%$ \\
\hline & pozostali & $80,2 \%$ \\
\hline
\end{tabular}

Źródło: opracowano własne.

i Oldham dotyczące satysfakcji z wynagrodzenia oraz pytania odnoszące się do zamiaru odejścia z pracy.

Do badania Przywiązania do Organizacji zastosowano polską adaptację Skali Przywiązania Organizacyjnego Allen i Meyer ${ }^{28}$. Narzędzie to zawiera trzy wymiary przywiązania do organizacji w postaci przywiązania emocjonalnego, normatywnego i kontynuacyjnego. Na każdą z trzech podskal tej miary przypada sześć pytań. Rzetelność dla wymiaru przywiązania emocjonalnego wyniosła $\alpha=0,84$, przywiązania normatywnego $\alpha=0,78$, przywiązania kontynuacyjnego $\alpha=0,83^{29}$.

Satysfakcję z pracy weryfikowano za pomocą Kwestionariusza Oceny Organizacji Michigan ${ }^{30}$. Miara ta składa się z trzech pytań. Odpowiedzi są udzielane

28 Ibidem.

29 Ibidem.

${ }^{30}$ C. Cammann, M. Fichman, D. Jenkins, J. Klesh, The Michigan Organizational Assessment Questionnaire, Unpublished manuscript, University of Michigan, Michigan-Ann Arbor 1979. 
na 7-stopniowej skali, od „zdecydowanie nie zgadzam się” do „zdecydowanie zgadzam się”. Rzetelność kwestionariusza wyniosła $\alpha=0,79$.

Zamiar odejścia mierzono, używając narzędzia składającego się z trzech pytań. Badani odpowiadali na 5-stopniowej skali Likerta, od „zdecydowanie nie zgadzam się” do „zdecydowanie zgadzam się”. Rzetelność tego narzędzia mierzona wskaźnikiem Cronbacha wyniosła $\alpha=0,94$.

Zadowolenie z wynagrodzenia było mierzone przy użyciu trzech pytań z Przeglądu Diagnostycznego Pracy Hackman i Oldham ${ }^{31}$. Odpowiedzi są udzielane na 5-stopniowej skali, od „zdecydowanie nie zgadzam się” do „zdecydowanie zgadzam się”. Rzetelność tej miary wyniosła $\alpha=0,95$.

Relacje między zmiennymi ujęte w hipotezach badawczych znalazły odzwierciedlenie w zaprezentowanym modelu (schemat 1 ).

W celu weryfikacji prawdziwości tego modelu zastosowano analizę równań strukturalnych metodą największego prawdopodobieństwa. Jej wybór był podyktowany odpowiednio dużym doborem próby oraz rozkładem zmiennych zastosowanych w badaniu zbliżonym do rozkładu normalnego, czego dowodem było to, że zarówno wartości kurtozy, jak i skośnej tych zmiennych mieściły się w przedziale (-2:2). Wybór analizy równań strukturalnych jako metody obliczania wyników był również spowodowany tym, że dawał możliwość identyfikowania siły zarówno pośredniego, jak i bezpośredniego wzajemnego odziaływania między zmiennymi.

Do weryfikacji modelu użyto najbardziej powszechnych wskaźników dopasowania modelu: normalizowany indeks dopasowania (Normed Fit Index - NFI), wskaźnik dobroci dopasowania (Goodness of Fit Index - GFI), wskaźnik dobroci dopasowania (Adjusted goodness of Fit Index - AGFI), indeks dopasowania porównawczego (Comparative Fit Index - CFI) i średniokwadratowy błąd aproksymacji (Root Mean Square Error of Approximation) - RMSEA).

Uzyskane wartości RMSEA $=0,017$ 90\% $(0,000 ; 0,094)$, NFI $=0,998$, $\mathrm{GFI}=0,998, \mathrm{AGFI}=0,983, \mathrm{CFI}=1, \mathrm{Chi}^{2}=2,27 ; \mathrm{df}=2 ; \mathrm{p}=0,320,(\mathrm{CMIN} /$ $\mathrm{DF}=1,13$ ) były dowodem na bardzo dobre dopasowanie modelu. Normalizowany indeks dopasowania (NFI) przewyższał krytyczny poziom 0,9, podobnie jak w przypadku AGFI - 0,9 i CFI - 0,93². Również wartość wskaźnika RMSA znalazła się zarówno znacząco poniżej akceptowalnego poziomu wynoszącego $0,08^{33}$. Ostateczny model uwzględniający istotne statystycznie wagi regresji został przedstawiony na schemacie 2 .

${ }^{31}$ R.J. Hackman, G.R. Oldham, Motivation through the design of work: test of a theory, „Organizational Behavior and Human Performance” 1976, nr 2(16), ss. 250-279.

${ }^{32}$ B.M. Byrne, Structural equation modeling with EQS and EQS/Windows, Sage Publications, ThousandOaks, CA, 1994.

${ }^{33}$ L. Hu, P.M. Bentler, Fit indices in covariance structure modeling: Sensitivity to underparameterized model misspecification, „Psychological Methods” $1998 \mathrm{nr}$ 4(3), ss. 424-453. 


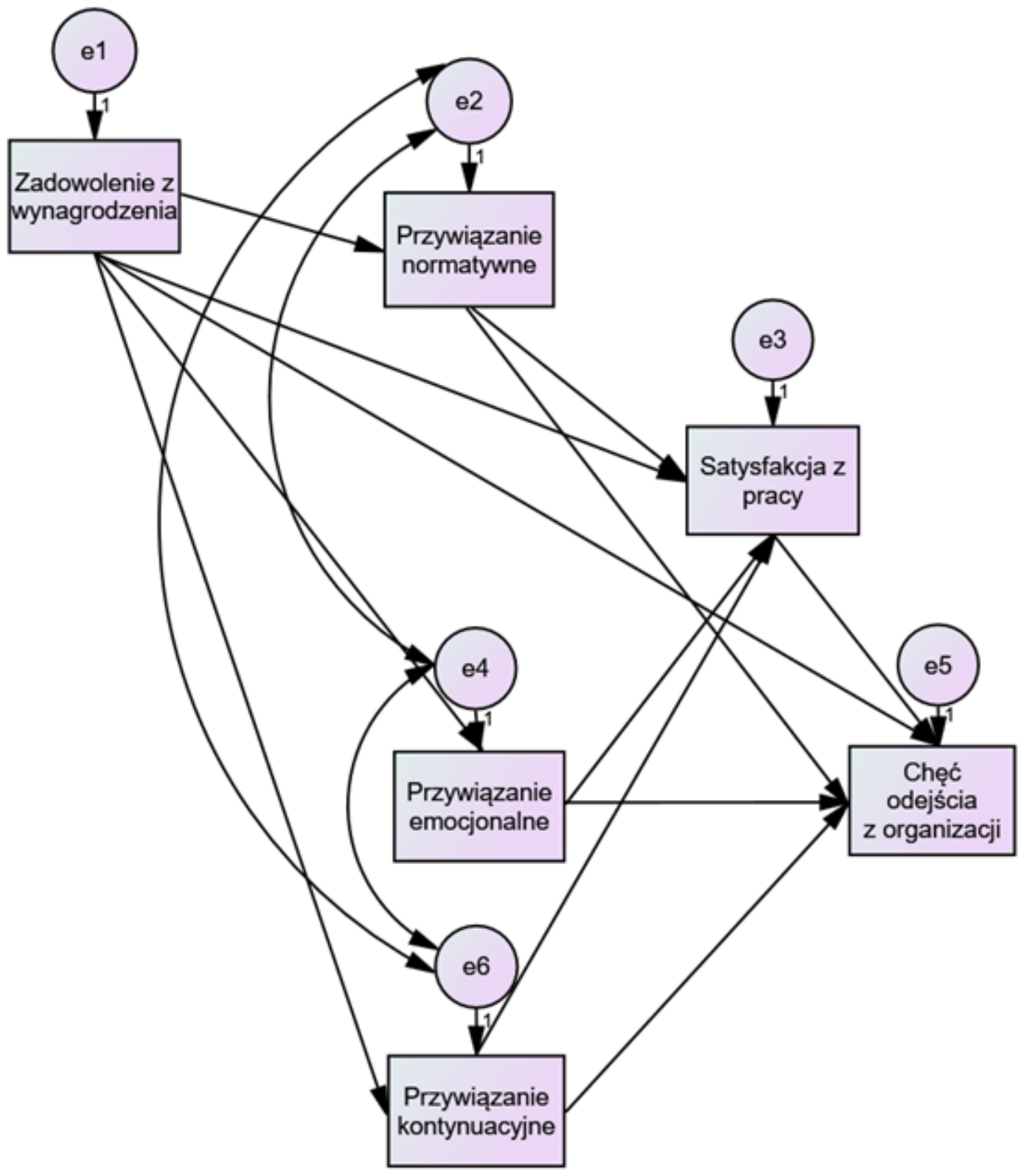

Schemat 1. Model relacji między zmiennymi odzwierciedlający hipotezy badawcze Źródło: opracowano własne. 


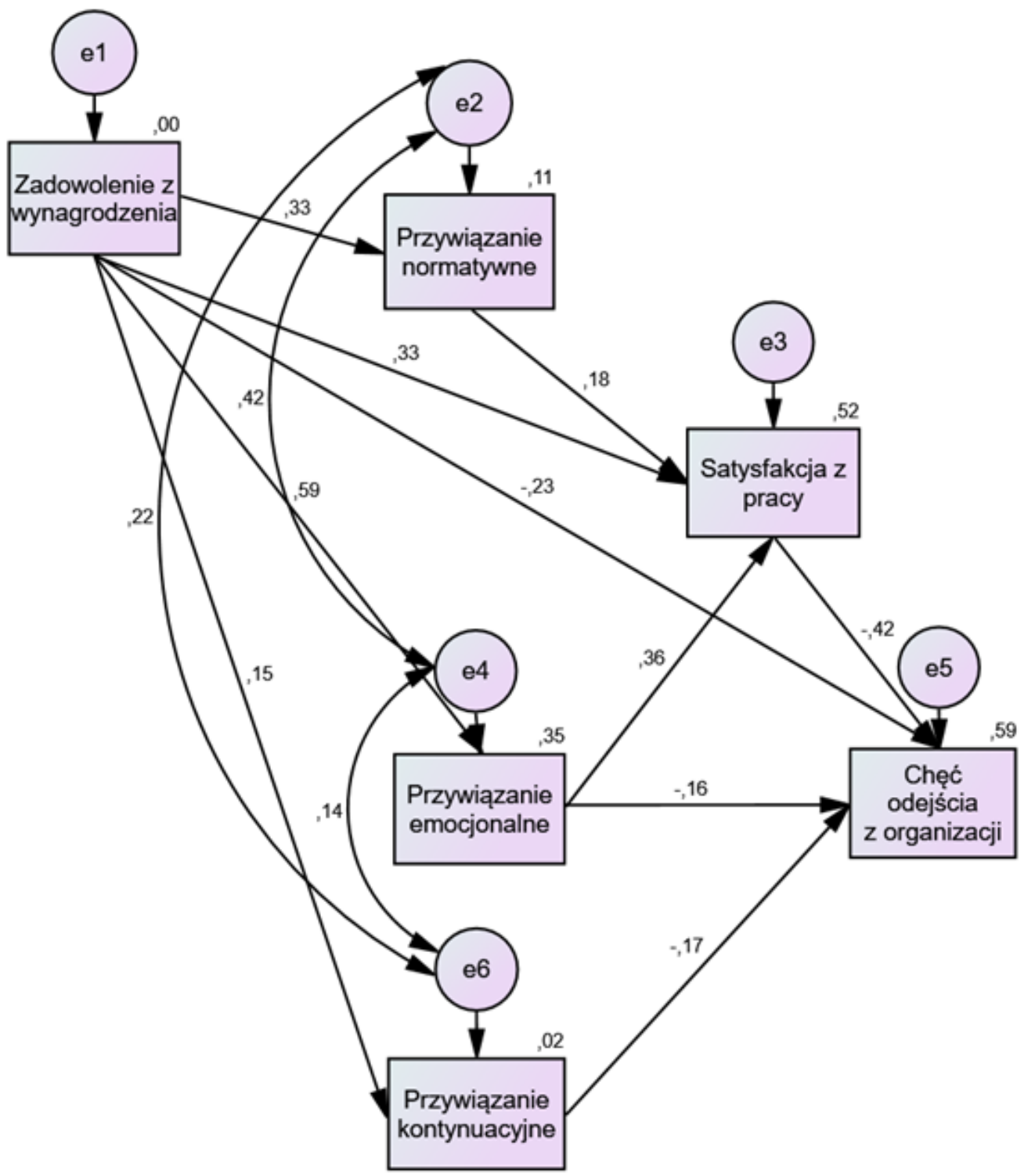

Schemat 1. Model końcowy

Źródło: opracowano własne. 


\section{Wyniki}

Statystyki opisowe zmiennych użytych w badaniu zostały zamieszczone w tabeli 2.

Tabela 2. Statystyki opisowe badanych zmiennych $(N=484)$

\begin{tabular}{|l|c|c|c|c|c|c|}
\hline $\begin{array}{c}\text { Zmienne użyte } \\
\text { w badaniu }\end{array}$ & $\begin{array}{c}\text { Satysfakcja } \\
\text { z pracy }\end{array}$ & $\begin{array}{c}\text { Satysfakcja } \\
\text { z wynagrodzenia }\end{array}$ & $\begin{array}{c}\text { Przywiązanie } \\
\text { emocjonalne }\end{array}$ & $\begin{array}{c}\text { Przywiązanie } \\
\text { kontynuacyjne }\end{array}$ & $\begin{array}{c}\text { Przywiązanie } \\
\text { normatywne }\end{array}$ & $\begin{array}{c}\text { Chęć odejścia } \\
\text { z pracy }\end{array}$ \\
\hline $\mathrm{N}$ & 484 & 484 & 484 & 484 & 484 & 484 \\
\hline Średnia & 14,04 & 7,56 & 19,40 & 17,39 & 19,04 & 8,34 \\
\hline Odchylenie st. & 4,28 & 3,50 & 5,24 & 5,01 & 4,76 & 3,66 \\
\hline Skośność &,- 410 &, 200 &,- 169 &, 014 &,- 152 &,- 169 \\
\hline $\begin{array}{l}\text { Błąd standardo- } \\
\text { wy skośności }\end{array}$ &, 111 &, 111 &, 111 &, 111 &, 111 &, 111 \\
\hline Kurtoza &,- 186 & $-1,060$ &,- 288 &,- 306 &, 075 & $-1,004$ \\
\hline $\begin{array}{l}\text { Błąd standardo- } \\
\text { wy kurtozy }\end{array}$ &, 222 &, 222 &, 222 &, 222 &, 222 &, 222 \\
\hline Minimum & 3 & 3 & 6 & 6 & 6 & 3 \\
\hline Maksimum & 21 & 15 & 30 & 30 & 30 & 15 \\
\hline
\end{tabular}

Źródło: opracowano własne.

Współczynnik korelacji r-Pearsona zaprezentowano w tabeli 3.

Tabela 3. Współczynniki korelacji r-Pearsona pomiędzy badanymi zmiennymi $(N=484)$

\begin{tabular}{|l|c|c|c|c|c|c|}
\hline \multicolumn{1}{|c|}{ Zmienne użyte w badaniu } & 1 & 2 & 3 & 4 & 5 & 6 \\
\hline 1. Chęć odejścia z pracy & - & - & - & - & - & - \\
\hline 2. Przywiązanie emocjonalne & $-0,61^{* *}$ & - & - & - & - & - \\
\hline 3. Przywiązanie kontynuacyjne & $-0,32^{* *}$ & $0,20^{* *}$ & - & - & - & - \\
\hline 4. Przywiązanie normatywne & $-0,42^{* *}$ & $0,51^{* *}$ & $0,25^{* *}$ & - & - & - \\
\hline 5. Satysfakcja z pracy & $-0,70^{* *}$ & $0,65^{* *}$ & $0,20^{* *}$ & $0,47^{* *}$ & - & - \\
\hline 6. Zadowolenie z wynagrodzenia & $-0,61^{* *}$ & $0,59^{* *}$ & $0,15^{* *}$ & $0,33^{* *}$ & $0,60^{* *}$ & - \\
\hline 7. Staż pracy & & & & & & $-0,16^{* *}$ \\
\hline
\end{tabular}

* korelacja istotna na poziomie 0,05

** korelacja istotna na poziomie 0,01

Źródło: opracowano własne. 
W stosunku do modelu wyjściowego zanotowano dwie zmiany w postaci braku związków pomiędzy przywiązaniem kontynuacyjnym do organizacji a satysfakcją z pracy oraz przywiązaniem normatywnym do organizacji a chęcią jej opuszczenia.

Przywiązanie kontynuacyjne okazało się nie być predyktorem satysfakcji $\mathrm{z}$ pracy (beta=0,034; $\mathrm{p}=0,225$ ), podobnie jak przywiązanie normatywne do organizacji dla zamiaru jej opuszczenia (beta=-0,019; $\mathrm{p}=0,479$ ). Wpływ pozostałych zmiennych na zamiar opuszczenia organizacji uwzględniający standaryzowany efekt całkowity, bezpośredni i pośredni został zaprezentowany w tabelach 4, 5, 6.

Tabela 4. Standaryzowany efekt całkowity $(n=484)$.

\begin{tabular}{|l|c|c|c|c|c|}
\hline $\begin{array}{l}\text { Zmienne uży- } \\
\text { te w badaniu }\end{array}$ & $\begin{array}{c}\text { Zadowolenie } \\
\text { z wynagrodzenia }\end{array}$ & $\begin{array}{c}\text { Przywiązanie } \\
\text { normatywne }\end{array}$ & $\begin{array}{c}\text { Przywiązanie } \\
\text { emocjonalne }\end{array}$ & $\begin{array}{c}\text { Przywiązanie } \\
\text { kontynuacyjne }\end{array}$ & $\begin{array}{c}\text { Satysfakcja } \\
\text { z pracy }\end{array}$ \\
\hline $\begin{array}{l}\text { Przywiązanie } \\
\text { normatywne }\end{array}$ & 0,33 & 0,00 & 0,00 & 0,00 & $0,00 \mathrm{t}$ \\
$\begin{array}{l}\text { Przywiązanie } \\
\text { emocjonalne }\end{array}$ & 0,60 & 0,00 & 0,00 & 0,00 & 0,00 \\
$\begin{array}{l}\text { Przywiązanie } \\
\text { kontynu- } \\
\text { acyjne }\end{array}$ & 0,15 & 0,00 & 0,00 & 0,00 & 0,00 \\
$\begin{array}{l}\text { Satysfakcja } \\
\text { z pracy }\end{array}$ & 0,60 & 0,18 & 0,35 & 0,00 & 0,00 \\
Chęć odejścia & $-0,61$ & $-0,07$ & $-0,31$ & $-0,17$ & $-0,42$ \\
\hline
\end{tabular}

Źródło: opracowanie własne.

Tabela 5. Standaryzowany efekt bezpośredni $(N=484)$

\begin{tabular}{|l|c|c|c|c|c|}
\hline \multicolumn{1}{|c|}{$\begin{array}{c}\text { Zmienne użyte } \\
\text { w badaniu }\end{array}$} & $\begin{array}{c}\text { Zadowolenie } \\
\text { z wynagrodzenia }\end{array}$ & $\begin{array}{c}\text { Przywiązanie } \\
\text { normatywne }\end{array}$ & $\begin{array}{c}\text { Przywiązanie } \\
\text { emocjonalne }\end{array}$ & $\begin{array}{c}\text { Przywiązanie } \\
\text { kontynuacyjne }\end{array}$ & $\begin{array}{c}\text { Satysfakcja } \\
\text { z pracy }\end{array}$ \\
\hline $\begin{array}{l}\text { Przywiązanie } \\
\text { normatywne }\end{array}$ & 0,33 & 0,00 & 0,00 & 0,00 & 0,00 \\
$\begin{array}{l}\text { Przywiązanie } \\
\text { emocjonalne }\end{array}$ & 0,59 & 0,00 & 0,00 & 0,00 & 0,00 \\
$\begin{array}{l}\text { Przywiązanie } \\
\text { kontynuacyjne }\end{array}$ & 0,15 & 0,00 & 0,00 & 0,00 & 0,00 \\
Satysfakcja z pracy & 0,33 & 0,18 & 0,36 & 0,00 & 0,00 \\
Chęć odejścia & $-0,23$ & 0,00 & $-0,16$ & $-0,17$ & $-0,42$ \\
\hline
\end{tabular}

Źródło: opracowanie własne. 
Tabela 6. Standaryzowany efekt pośredni $(N=484)$

\begin{tabular}{|l|c|c|c|c|c|}
\hline \multicolumn{1}{|c|}{$\begin{array}{c}\text { Zmienne użyte } \\
\text { w badaniu }\end{array}$} & $\begin{array}{c}\text { Zadowolenie } \\
\text { z wynagrodzenia }\end{array}$ & $\begin{array}{c}\text { Przywiązanie } \\
\text { normatywne }\end{array}$ & $\begin{array}{c}\text { Przywiązanie } \\
\text { emocjonalne }\end{array}$ & $\begin{array}{c}\text { Przywiązanie } \\
\text { kontynuacyjne }\end{array}$ & $\begin{array}{c}\text { Satysfakcja } \\
\text { z pracy }\end{array}$ \\
\hline $\begin{array}{l}\text { Przywiązanie } \\
\text { normatywne }\end{array}$ & 0,00 & 0,00 & 0,00 & 0,00 & 0,00 \\
$\begin{array}{l}\text { Przywiązanie } \\
\text { emocjonalne }\end{array}$ & 0,00 & 0,00 & 0,00 & 0,00 & 0,00 \\
$\begin{array}{l}\text { Przywiązanie } \\
\text { kontynuacyjne }\end{array}$ & 0,00 & 0,00 & 0,00 & 0,00 & 0,00 \\
Satysfakcja z pracy & 0,27 & 0,00 & 0,00 & 0,00 & 0,00 \\
Chęć odejścia & $-0,38$ & $-0,07$ & $-0,15$ & 0,00 & 0,00 \\
\hline
\end{tabular}

Źródło: opracowanie własne.

Przywiązanie normatywne okazało się tylko pośrednio związane z zamiarem odejścia z organizacji, a zmienną mediacyjną w tej relacji była satysfakcja z pracy. Efekt bezpośredni oddziaływania zadowolenia z wynagrodzenia na chęć opuszczenia organizacji był większy od efektu bezpośredniego. Zmiennymi, które pośredniczyły w tej relacji, była satysfakcja z pracy, przywiązanie emocjonalne i przywiązanie kontynuacyjne. Mediatorem pomiędzy przywiązaniem emocjonalnym a zamiarem opuszczenia organizacji była satysfakcja z pracy. Efekt bezpośredniego wpływu przywiązania emocjonalnego na chęć opuszczenia organizacji był większy niż efekt pośredni poprzez satysfakcję z życia.

\section{Dyskusja}

Hipoteza pierwsza zakładająca, że wszystkie trzy wymiary przywiązania do organizacji oddziałują zarówno bezpośrednio, jak i pośrednio na chęć jej opuszczenia, została w znacznej mierze potwierdzona. Zgodnie z dotychczasowymi wynikami badań satysfakcja z pracy pośredniczyła częściowo między przywiązaniem emocjonalnym do organizacji a zamiarem jej opuszczenia ${ }^{34}$, co oznacza, że pracownicy odczuwający pozytywną więź z organizacją oraz dumę z bycia jej członkiem są bardziej usatysfakcjonowani z pracy, czego konsekwencją jest ich mniejsza chęć opuszczenia organizacji.

Niezgodnie z oczekiwaniami przywiązanie kontynuacyjne do organizacji było tylko bezpośrednio związane z chęcią opuszczenia organizacji, co oznacza, że zmienna ta kształtuje motywację do odejścia z organizacji bez udziału satysfakcji

${ }^{34}$ C. Anton, The impact of role stress on workers'behaviour...; C.M. Riordan, R.W. Griffeth, The opportunity for friendship in the workplace... 
z pracy. Przywiązanie normatywne nie było bezpośrednio związane z chęcią opuszczenia organizacji, oddziałując na tę zmienną poprzez satysfakcję z pracy. Oznacza to, że pracownicy, którzy odczuwają lojalność wobec organizacji oraz wewnętrzną powinność, aby w niej pozostać, są bardziej usatysfakcjonowani z pracy, czego konsekwencją jest brak chęci jej opuszczenia. Dotychczasowe wyniki badań przeprowadzonych w Polsce potwierdzają pozytywne związki między przywiązaniem organizacyjnym pracowników a ich satysfakcją z pracy. W badaniach Łukasza Baki $^{35}$ przywiązanie do organizacji było negatywnie związane z poziomem afektu negatywnego w pracy, co oznacza, że niezależnie od typu przywiązania do organizacji więź z organizacją jest związana z mniejszą ilością negatywnych emocji dotyczących organizacji. W badaniach Aleksandry Peplińskiej i współpracowników ${ }^{36}$ satysfakcja z pracy rozumiana jako zadowolenie z kolegów, przełożonego, zarobków i awansu była pozytywnie skorelowana z przywiązaniem emocjonalnym do organizacji. Również Dagmara Lewicka i Paulina Rożenek ${ }^{37}$ potwierdziły rolę zarówno przywiązania emocjonalnego i przywiązania normatywnego, jak również przywiązania trwania opartego na obawach oraz przywiązania trwania opartego na korzyściach dla ogólnej satysfakcji z pracy pracowników.

Na podstawie otrzymanych rezultatów można stwierdzić, że związki między przywiązaniem do organizacji i satysfakcją z pracy a chęcią jej opuszczenia są uzależnione od tego, jaki typ przywiązania organizacyjnego jest brany pod uwagę. Oznacza to, że powyższych relacji nie można sprowadzić do jednego uniwersalnego modelu. Otrzymane wyniki są częściowo zgodne z dotychczasowymi rezultatami badań, dowodząc, że przywiązanie emocjonalne oraz satysfakcja z pracy są odrębnymi predyktorami chęci opuszczenia organizacji, a satysfakcja z pracy częściowo pośredniczy między przywiązaniem do organizacji a zamiarem jej opuszczenia. Pracownicy przejawiający przywiązanie emocjonalne do organizacji, to znaczy tacy, którzy identyfikują się z organizacją i jej celami oraz odczuwają dumę z bycia jej członkiem, są bardziej usatysfakcjonowani z pracy, co powoduje, że mają mniejszą motywację do jej opuszczenia. Również osoby, które odczuwają powinność pozostania w organizacji, czyli deklarują wysoki poziom przywiązania normatywnego, są bardziej zadowoleni z pracy, co w konsekwencji ma wpływ na to, że nie mają zamiaru jej zmieniać. W przypadku pracowników, którzy nie chcą zmieniać pracy ze względu na przywiązanie kontynuacyjne charakteryzujące się

${ }^{35}$ Ł. Baka, Stresory w pracy a zachowania kontrproduktywne. Pośredniczqca rola negatywnego afektu, przywiqzania organizacyjnego i zaangażowania w pracy, „Studia Psychologiczne” 2012, nr 2(50), ss. 25-42.

${ }^{36}$ A. Peplińska, D. Godlewska-Werner, S. Celińska, Z. Nieckarz, P. Połomski, Przywiq̨zanie do organizacji i motywacja do pracy a poziom materializmu pracowników - pośredniczq̨ca rola satysfakcji z pracy, „Zarządzanie Zasobami Ludzkimi” 2018, nr 1(120), ss. 11-30.

${ }_{77}$ D. Lewicka, P. Rożenek, Determinanty przywiq̨zania afektywnego, „Zeszyty Naukowe Wyższej Szkoły Humanitas Zarządzanie” 2016, nr 17(1), ss. 225-238. 
obawą przed utratą korzyści wynikających z aktualnego miejsca zatrudnienia, ich postawa wobec pracodawcy nie jest związana z satysfakcją z pracy. Oznacza to, że bilans zysków i strat, który podpowiada im, aby nie zmieniali pracodawcy, jest niezależny od poziomu satysfakcji z pracy. W ich przypadku jedyną przesłanką motywującą ich do pozostania w organizacji jest „rachunek biznesowy”, w ramach którego ich zadowolenie z pracy nie odgrywa żadnej roli.

Hipoteza druga, zgodnie z którą zadowolenie z wynagrodzenia oddziałuje zarówno bezpośrednio, jak i pośrednio poprzez satysfakcję z pracy na chęć opuszczenia organizacji, została w pełni potwierdzona. Uzyskane rezultaty są zgodne z dotychczasowymi wynikami badań, wskazując na fakt, iż satysfakcja z pracy oraz zadowolenie z wynagrodzenia są odrębnymi predyktorami zamiaru odejścia z organizacji, a równocześnie satysfakcja z pracy jest częściowym mediatorem pomiędzy zadowoleniem z wynagrodzenia i chęcią jej opuszczenia ${ }^{38}$. Oznacza to, że pracownicy zadowoleni ze swojego wynagrodzenia są również usatysfakcjonowani z pracy, co w konsekwencji powoduje, że nie mają chęci opuszczenia organizacji.

Również hipoteza trzecia zakładająca, że wszystkie trzy wymiary przywiązania do organizacji w pewnym stopniu pośredniczą między zadowoleniem z wynagrodzenia a chęcią opuszczenia organizacji, została częściowo potwierdzona. Zgodnie z dotychczasowymi wynikami badań przywiązanie emocjonalne oraz przywiązanie kontynuacyjne częściowo pośredniczyły między zadowoleniem z wynagrodzenia a chęcią odejścia z pracy, co oznacza, że pracownicy zadowoleni ze swojego wynagrodzenia są bardziej przywiązani emocjonalnie oraz kontynuacyjnie do organizacji, czego efektem jest brak chęci jej opuszczenia. Niespójnie z rezultatami otrzymanymi przez Tan i Akhtar ${ }^{39}$ przywiązanie normatywne nie pośredniczyło między zadowoleniem z wynagrodzenia a chęcią opuszczenia organizacji.

Przeprowadzone badania potwierdziły trzy mechanizmy wpływu zadowolenia z wynagrodzenia na chęć opuszczenia organizacji: bezpośredni, za pośrednictwem satysfakcji z pracy, jak również za pośrednictwem przywiązania emocjonalnego i kontynuacyjnego. Pracownicy zadowoleni z wynagrodzenia mają większą satysfakcją z pracy, co powoduje, że mają mniejszą motywację do odejścia z organizacji. Innym motywatorem braku chęci opuszczenia organizacji jest przywiązanie emocjonalne i kontynuacyjne, będące efektem zadowolenia z wynagrodzenia. Oznacza to, że zatrudnieni, którzy są zadowoleni z wynagrodzenia, nie mają zamiaru opuszczać organizacji, czerpiąc satysfakcję i dumę z trwania w organizacji lub odczuwając wewnętrzny przymus, aby w niej pozostać z obawy przed utratą przywilejów i benefitów.

${ }^{38}$ L. Lum, J. Kervin, K. Clark, F. Reid, W. Sirola, Explaining nursing turnover intent...

39 D. Tan, S. Akhtar, Comparison of job-facet satisfaction and commitment... 
Tak samo jak wśród pracowników hotelu w Turcji długość zatrudnienia miała pozytywny wpływ na chęć jej opuszczenia ${ }^{40}$, co oznacza, że im dłużej badani pracowali w organizacji, tym większą motywację do zmiany pracy deklarowali. Niezgodnie z niektórymi dotychczasowymi wynikami badań zatrudnieni dłużej w organizacji deklarowali mniejszą satysfakcję z pracy ${ }^{41}$ oraz mniejsze zadowolenie z wynagrodzenia ${ }^{42}$. Rozbieżności w stosunku do dotychczasowych wyników badań mogą wynikać zarówno ze specyfiki danej organizacji i jej kultury organizacyjnej, jak również z powodu tego, że staż pracy był ujęty jako zmienna porządkowa, a nie ilorazowa.

Warto zasygnalizować istnienie implikacji praktycznych wynikających z przeprowadzonych badań. Wskazują one na różne motywy pozostania pracowników w organizacji, będąc istotnym źródłem wiedzy, zarówno dla osób zarządzających w organizacjach, jak również przedstawicieli działów zarządzania zasobami ludzkimi. Dowodzą one, iż zarówno zadowolenie z wynagrodzenia, jak i przywiązanie do organizacji są istotnymi przesłankami dla chęci opuszczenia organizacji. W związku z tym pracodawcy oraz ich reprezentanci powinni zadbać o to, aby zatrudnieni pracownicy byli jak najbardziej zadowoleni ze swojego wynagrodzenia, szukając indywidualnych i zróżnicowanych sposobów na osiągnięcie tego celu. Jednym z nich może być uświadamianie pracownikom wysokości wynagrodzenia jako atrakcyjnego w porównaniu do wynagrodzeń na analogicznych lub podobnych stanowiskach w innych organizacjach. Cel ten można osiągnąć również poprzez przekonywanie pracowników o tym, że ich wynagrodzenie jest sprawiedliwe, czyli adekwatne do posiadanych przez nich umiejętności, odpowiedzialności w pracy czy przeżywanego stresu.

Innym sposobem na utrzymanie pracowników w miejscu pracy oraz kształtowania u nich satysfakcji z pracy powinno być odziaływanie na przywiązanie do organizacji, oparte na założeniu, że wszystkie trzy typy przywiązania charakteryzują się odmiennymi uwarunkowaniami, a każdy pracownik w pewnym stopniu reprezentuje je wszystkie. Daje to organizacjom duże możliwości kształtowania przywiązania do organizacji, a co za tym idzie, wpływu na satysfakcję oraz motywację do pozostania w aktualnym miejscu pracy. Przełożeni powinni potrafić identyfikować wśród swoich podwładnych ich wiodący przejaw przywiązania do organizacji i w relacjach z nimi odwoływać się do wartości stanowiących przesłanki charakterystyczne dla danego wymiaru przywiązania do organizacji. Dla osób

40 B.D. Emiroğlu, O. Akova, H. Tanrıverdi, The relationship between turnover intention and demographic factors in hotel businesses: A study at five star hotels in Istanbut, „Procedia - Social and Behavioral Sciences” 2015, nr 207, ss. 385-397.

${ }^{41}$ C.R. Williams, Reward contingency, unemployment, and functional turnover, „Human Resource Management Review” 1999, nr 9(4), ss. 549-576.

${ }^{42}$ L.R. Gómez-Mejia, D.B. Balkin, Faculty satisfaction with pay and other job dimensions under union and nonunion conditions, „Academy of Management Journal” 1984, nr 27, ss. 591-602. 
preferujących przywiązanie emocjonalne argumentem na rzecz pozostania może być duma z pracy w przedsiębiorstwie i jej wyjątkowość w porównaniu z innymi organizacjami. Wobec pracowników, u których dominuje przywiązanie normatywne, ważne może być poczucie moralnego obowiązku, bezpieczeństwa zatrudnienia i stabilizacji, natomiast wśród tych, którzy charakteryzują się wysokim poziomem przywiązania kontynuacyjnego, mogą odwoływać się do pozycji osiągniętej przez podwładnego w organizacji, jak również korzyści i zysków z pozostania w organizacji w kontraście do zagrożeń i potencjalnych strat wynikających z jej opuszczenia.

Przeprowadzone badania mają pewne ograniczenia. Przede wszystkim ich rezultaty odnoszą się tylko i wyłącznie do pracowników badanej organizacji. Jest to wynik homogeniczności badanej populacji, na wyniki której istotny wpływ mogła mieć kultura organizacyjna badanego przedsiębiorstwa.

Również poprzeczny, a nie podłużny charakter badań uniemożliwia przedstawienie ich wyników w perspektywie przyczynowo-skutkowej, ograniczając możliwości ich interpretacji do określenia kierunku relacji zastosowanych zmiennych. Kolejne badania w odniesieniu do tej tematyki powinny być przeprowadzone na bardziej zróżnicowanej grupie badanych pochodzących z różnych organizacji przy użyciu również afektywnych miar zadowolenia z pracy oraz wskaźników zadowolenia z różnych aspektów pracy, takich jak możliwości awansu, atmosfery czy relacji z przełożonym.

\section{Literatura}

A'yuninnisa R.N., Saptoto R., The effects of pay satisfaction and affective commitment on turnover intention, „International Journal of Research Studies in Psychology” 2015, nr 2(4).

Allen N.J., Meyer J.P., A three-component conceptualization of organizational commitment, „Human Resource Management Review” 1991, nr 1(1).

Allen N.J., Meyer J.P., Affective, continuance, and normative commitment to the organization: An examination of construct validity, „Journal of Vocational Behavior” 1996, nr 3(49).

Allen N.J., Meyer J.P., The measurement and antecedents of affective, continuance, and normative commitment to the organization, „Journal of Occupational Psychology” 1990, nr 63.

Anton C., The impact of role stress on workers' behaviour through job satisfaction and organizational commitment, „Interna-tional Journal of Psychology” 2009, nr 3(44).

Baka Ł., Stresory w pracy a zachowania kontrproduktywne. Pośredniczq̨ca rola negatywnego afektu, przywiqzania organizacyjnego i zaangażowania w pracy, „Studia Psychologiczne” 2012, nr 2(50).

Breukelen W. van, Vlist R. van der, Steensma H., Voluntary employee turnover: combining variables for the traditional turnover literature with the theory of planned behavior, „Journal of Organizational Behavior” 2004, nr 25. 
Byrne B.M., Structural equation modeling with EQS and EQS/Windows, Sage Publications, ThousandOaks, CA, 1994.

Cammann C., Fichman M., Jenkins D., Klesh J., The Michigan Organizational Assessment Questionnaire, Unpublished manuscript, University of Michigan, Michigan-Ann Arbor 1979.

Emiroğlu B.D., Akova O., Tanrıverdi H., The relationship between turnover intention and demographic factors in hotel busi-nesses: A study at five star hotels in Istanbut, „Procedia - Social and Behavioral Sciences” 2015, nr 207(20).

Fundowicz J., Łapiński K., Peterlik M., Wyżnikiewicz B., Szara strefa w polskiej gospodarce w 2016 roku, Instytut Badań Nad Gospodarką Rynkową, Warszawa 2016.

Gómez-Mejia L.R., Balkin D.B., Faculty satisfaction with pay and other job dimensions under union and nonunion conditions, „Academy of Management Journal” 1984, nr 27.

Gouldner A.W., The norm of reciprocity: A preliminary statement, „American Sociological Review” 1960, nr 2(25).

Guimaraes T., Igbaria M., Antecedents and consequences of job satisfaction among information center employees, „Journal of Management Information Systems” 1993, nr 4(9).

Hackman R.J., Oldham G.R., Motivation through the design of work: test of a theory, „Organizational Behavior and Human Performance” 1976, nr 2(16).

Hu L., Bentler P.M., Fit indices in covariance structure modeling: Sensitivity to underparameterized model misspecification, „Psychological Methods” $1998 \mathrm{nr}$ 4(3).

Kanter R.M., Commitment and Community, Harvard University Press, Cambridge 1976.

Lewicka D., Rożenek P., Determinanty przywiqzzania afektywnego, „Zeszyty Naukowe Wyższej Szkoły Humanitas Zarządzanie” 2016, nr 1(17).

Locke E.A., The nature and causes of job satisfaction, w: Handbook of industrial and organizational psychology, red. M.D. Dunnette, Rand McNally, Chicago 1976.

Lum L., Kervin J., Clark K., Reid F., Sirola W., Explaining nursing turnover intent: job satisfaction, pay satisfaction, or organizational commitment?, „Journal of Organizational Behavior" $1998 \mathrm{nr}$ 3(19).

Meyer J.P., Stanley D.J., Herscovitch L., Topolnytsky L., Affective, continuance, and normative commitment to the organiza-tion: A meta-analysis of antecedents, correlates, and consequences, „Journal of Vocational Behavior” 2002, nr 61.

Organ D.W., Near J.P., Cognitive vs. affect measures of job satisfaction, „International Journal of Psychology” 1985, nr 20.

Peplińska A., Godlewska-Werner D., Celińska S., Nieckarz Z., Połomski P., Przywiqzzanie do organizacji i motywacja do pracy a poziom materializmu pracowników - pośredniczq̨ca rola satysfakcji z pracy, „Zarządzanie Zasobami Ludzkimi” 2018, nr 120(1).

Riordan C.M., Griffeth R.W., The opportunity for friendship in the workplace: An underexplored construct, „Journal of Business and Psychology” 1995, nr 10.

Stachowska S., Oczekiwania przedstawicieli pokolenia $Y$ wobec pracy i pracodawcy, „Zarządzanie Zasobami Ludzkimi” 2012, nr 2(85).

Tan D., Akhtar S., Comparison of job-facet satisfaction and commitment, determinants of turnover intention, „The International Journal of Employment Studies” 1995 3(1).

Tett R.P., Meyer J.P., Job satisfaction, organizational commitment, turnover intention, and turnover: Path analyses based on meta-analytic findings, „Personnel Psychology” 1993, nr 46. 
Trimble D.E., Organizational commitment, job satisfaction, and turnover intention of missionaries, „Journal of Psychology and Theology” 2006, nr 4(34).

Vandenberghe Ch., Tremblay M., The role of pay satisfaction and organizational commitment in turnover intentions: A two-sample study, „Journal of Business Psychology” 2008, nr 22.

Williams C.R., Reward contingency, unemployment, and functional turnover, „Human Resource Management Review” 1999, nr 9(4).

Wnuk M., Hedonizm, eudajmonizm oraz przepływ/zaangażowanie jako trzy nurty badań nad szczęściem, „Hygeia Public Health” 2013, nr 3(48).

Wnuk M., Właściwości psychometryczne polskiej wersji Skali Przywiqzzania do Organizacji autorstwa Allen i Meyer, „Organizacja i Kierowanie” 2017, nr 3(177).

Zalewska A., Reactivity and Job Satisfaction at a New Workplace, „Polish Psychological Bulletin” 2001, nr 3(32). 
